\title{
PENINGKATAN KOMPETENSI NETWORK ENGINEER BAGI SISWA PROGRAM STUDI TEKNIK KOMPUTER JARINGAN SMK TEKNOLOGI KARAWANG MELALUI PELATIHAN MIKROTIK
}

\author{
Anggi Elanda ${ }^{1}$, Asep Samsul Bakhri², Yudiana ${ }^{3}$, Dhian Nur Rahayu ${ }^{4}$ \\ 1,2,3,4Program Studi Teknik Informatika, STMIK ROSMA \\ Email : ${ }^{1}$ anggi@rosma.ac.id, 2asep.bahri@dosen.rosma.ac.id, ${ }^{3}$ yudiana@dosen.rosma.ac.id, \\ 4dhian.rahayu@dosen.rosma.ac.id
}

Diterima : 10-06-2021, Di publikasikan : 16-06-2021

\begin{abstract}
Abstrak
Program studi Teknik Komputer Jaringan (TKJ) pada Sekolah Menengah Kejuruan (SMK) memiliki beberapa profil lulusan, salah satunya menjadi seorang Network Engineer. Profil tersebut memiliki kompetensi dalam manajemen router. Pelatihan Mikrotik menjadi salah satu media untuk meningkatkan kompetensi siswa dalam manajemen router. Pada kegiatan ini, mitra yang diundang untuk mengikuti pelatihan mikrotik adalah siswa prodi TKJ SMK TEKNOLOGI KARAWANG. Tujuan kegiatan ini adalah memberikan bekal siswa dalam manajemen router, sehingga dapat meningkatkan minat menjadi seorang network engineer. Prosedur yang dilakukan pada kegiatan ini di mulai dengan melakukan pretest, penjadwalan, persiapan marteri, pelaksanaan dan evaluasi kegiatan. Kegiatan diikuti oleh 30 peserta yang berasal dari kelas XII. Hasil kegiatan ini menunjukkan adanya peningkatan pemahaman dari peserta. Peserta berhasil melakukan simulasi manajemen router statik dan manajemen hotspot. Implikasi dari kegiatan ini adalah peningkatan minta profesi network engineer di kalangan SMK khususnya program studi TKJ.
\end{abstract}

Kata Kunci : Mikrotik, Network Engineer, Router, Teknik Komputer Jaringan.

Abstract

The Computer Network Engineering (TKJ) study program at the Vocational High School (SMK) has several graduate profiles, one of which is becoming a network engineer. The profile has competence in router management. Mikrotik training is one of the media to improve student competence in router management. In this activity, partners who were invited to take part in the mikrotik training were students of the TKJ study program at SMK TEKNOLOGI KARAWANG. The purpose of this activity is to provide students with provisions in router management, so that they can increase their interest in becoming a network engineer. The procedure carried out in this activity begins with conducting a pretest, scheduling, material preparation, implementation and evaluation of activities. The activity was attended by 30 participants from class XII. The results of this activity indicate an increase in the understanding of the participants. Participants succeeded in simulating static router management and hotspot management. The implication of this activity is the increase in demand for the network engineer profession among vocational schools, especially the TKJ study program.

Keyword : Mikrotik, Network Computer Engineering, Network Engineer, Router

\section{PENDAHULUAN}

Meningakatnya adopsi teknologi pada dunia usaha dan industri, mendorong peningkatan kebutuhan sumber daya profesional pengelola teknologi. Beberapa profesi yang mendukung implementasi adopsi teknologi adalah Network Engineer, Network Administrator, ERP (Enterprise Resource Planning) Support, IT Support, dan lain - lain. Menurut situs Job Street mencatat ada sekitar 684 jobs per hari untuk kebutuhan network engineer (Job Street, 2021). Sedangkan situs JobsDB mencatat ada sekitar 639 jobs per hari untuk kebutuhan network engineer (JobsDB, 2021). Glints menjelasakan network engineer bertanggung jawab atas keberlangsungan dan stabilitas jaringan sebuah organisasi (Glints, 2021). Keberlangsungan ini dapat berarti monitoring trafik data, suara, video dan lain - lain. Selain 
monitoring, Network Engineer juga melakukan pengaturan secara rutin. Pengaturan dan monitoring tersebut, berhubungan dengan manajemen router. Router merupakan perangkat penting pada suatu jaringan yang mendukung lalu lintas data (Ridho, Yudhana, \& Riadi, 2016). Selain itu router juga berfungsi memberikan batas antara network local dengan network internet (Tasanah Assakur, Fahrudin, \& Ferdiansyah, 2020). Menurut Hadriyanto (2016) menjelaskan bahwa router adalah perangkat yang akan melewatkan paket IP dari suatu jaringan ke jaringan yang lain menggunakan metode addressing dan protocol tertentu untuk melewatkan pakat data (Hafiz et al., 2021). Mikrotik merupakan sistem operasi yang dikhususkan untuk menangani routing pada jaringan (Rahman, Sumarna, \& Nurdin, 2020). Mitra pada kegiatan ini adalah Program Studi Teknik Komputer Jaringan SMK TEKNOLOGI KARAWANG yang bertujuan untuk meningkatkan penyerapan lulusan sesuai bidang profesinya. Kegiatan ini dapat mendukung peningkatan kompetensi siswa dalam hal manajemen router mikrotik, sehingga berimplikasi mendorong penyerapan lulusan di dunia industri dan usaha. Manajemen router mikrotik terbukti dapat mendukung industri dalam pengelolaan implementasi teknologi, hal ini diungkap dalam beberapa penelitian diantaranya (Sistem, 2021), (Ridho et al., 2016), (Kurniawan et al., 2021).

\section{METODE}

Prosedur pada kegiatan ini diawali dengan evaluasi awal atau pre-test yang bertujuan untuk mengevaluasi pemahaman awal peserta pelatihan mengenai konsep router dan manajemennya. Berdasarkan hasil evaluasi awal, disusun materi untuk pelatihan. Setelah disusun materi, dilakukan koordinasi dengan mitra terkait penjadwalan kegiatan. Prosedur selanjutnya adalah pelaksanaan kegiatan dan evaluasi kegiatan. Evaluasi disusun berdasarkan materi yang telah disiapkan dan disampaikan pada saat pelaksanaan kegiatan.

\section{HASIL DAN PEMBAHASAN}

Pelaksanaan kegiatan pelatihan Router Mikrotik ini dilaksanakan pada tanggal 12 sampai dengan 13 Oktober 2020. Hari pertama diisi dengan penyajian materi mengenai konsep dasar TCP/IP, selanjutnya peserta diberikan contoh setup internet connection melalui router. Pemateri dari pelatihan ini berasal dari Dosen yang spesialis mengajar mata kuliah jaringan komputer. Berdasarkan contoh pemateri, peserta pelatihan diminta untuk mengikuti contoh. Hasilnya terlihat, peserta berhasil melakukan setup internet connection melalui router. Setelah berhasil, materi dilanjutkan dengan upgrade RouterOS dan manage routerOS service serta backup dan export atau import configuration. Selain itu juga peserta diberikan pemahaman tentang RouterOS license.

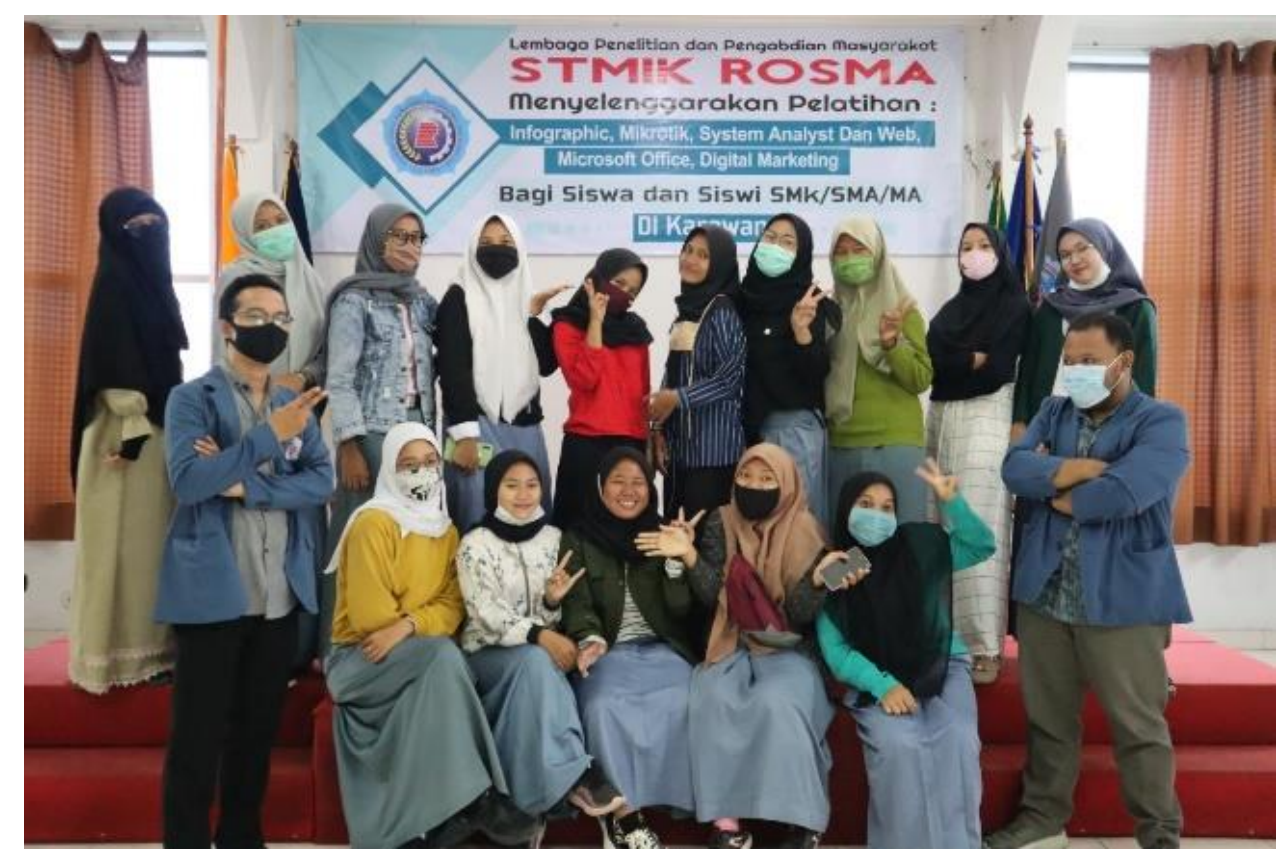

Gambar 1. Pelatihan Mikrotik 


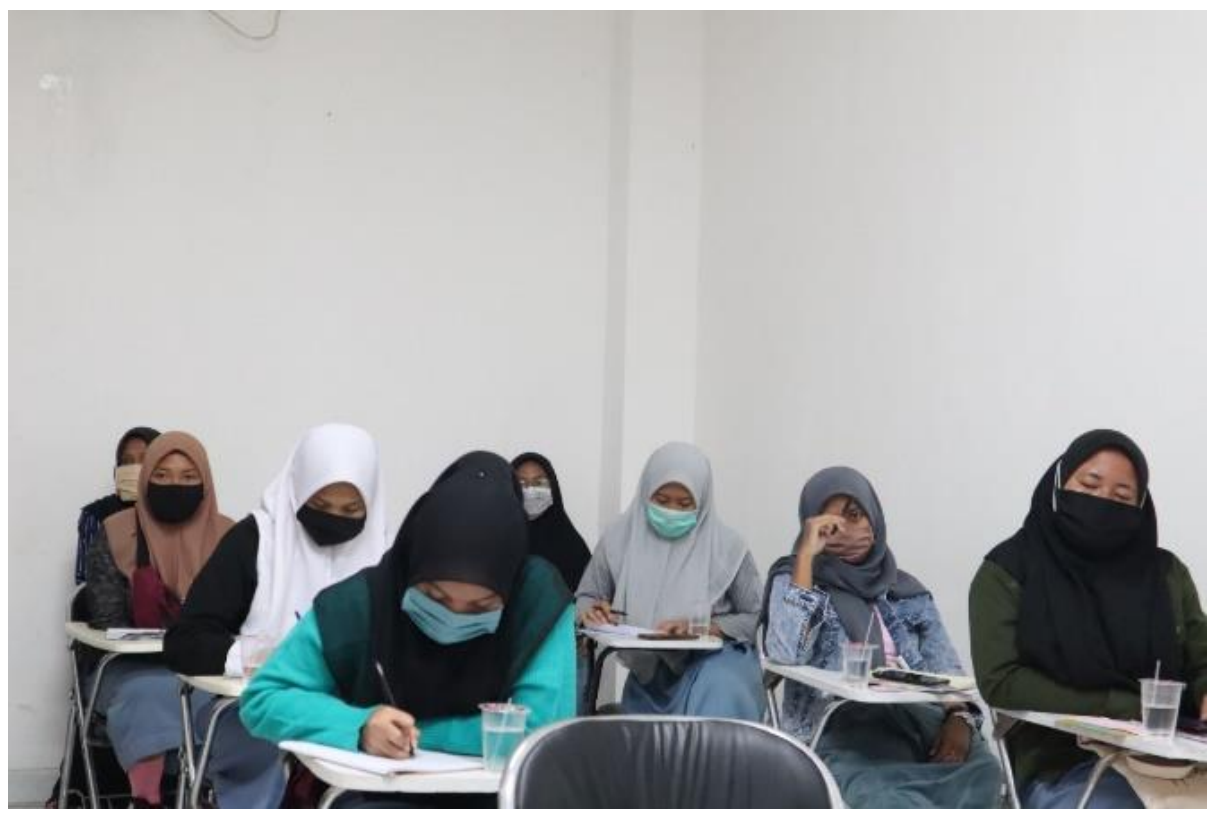

Gambar 2. Pelatihan Mikrotik

Hari kedua pelatihan, difokuskan pada evaluasi materi, dengan memberikan studi kasus pada peserta pelatihan. Kasus studi yang diangkat adalah manajemen router static dan manajemen hotspot. Pada kegiatan evalausi ini, peserta antusias menyelesaikan studi kasus yang telah diberikan pemateri. Di beberapa peserta terlihat ada yang kurang memahami terhadap penerapan kasus tersebut, kemudian pemateri memberikan contoh penyelesain kasus, dan peserta diminta untuk mengulangi penyelesaian masalah studi kasus tersebut. Pada akhir evaluasi, akhirnya seluruh peserta berhasil melakukan manajemen router dan manajemen hotspot.

\section{KESIMPULAN DAN SARAN}

Pelatihan Router Mikrotik dengan tujuan untuk meningkatkan minat lulusan prodi TKJ SMK TEKNOLOGI KARAWANG dapat berjalan lancar, dan seluruh peserta antusias mencoba dan mempraktekkan materi yang telah disajikan oleh pemateri. Hasil penelitian ini dapat terlihat dari sesi evaluasi. Peserta dapat menerapkan pemahamnnya pada studi kasus yang diberikan. Melalui kegiatan ini, memungkinkan peningkatan minat siswa untuk menjadi seorang Network Engineer, sehingga dapat berimplikasi pada mitra yaitu prodi TKJ SMK TEKNOLOGI KARAWANG yaitu peningkatan penyerapan lulusan oleh Industri.

\section{UCAPAN TERIMA KASIH}

Ucapan terima kasih disampaikan kepada UPT TIK STMIK ROSMA yang telah memberikan ruang kepada kami, serta Kepala Sekolah, Guru dan Siswa program studi TKJ SMK TEKNOLOGI KARAWANG yang telah berperan dalam kegiatan ini.

\section{REFFERENCE}

Glints. (2021). Network Engineer. Retrieved June 9, 2021, from Gkints website: https://glints.com/id/lowongan/berkenalan-lebih-dalam-dengan-profesi-networkengineer/\#.YMAob_kzaMo

Hafiz, A., Kurnia, I., Studi, P., Informatika, M., Studi, P., Informatika, M., ... Approach, D. (2021). MENGEMBANGKAN JARINGAN WIRELESS LOCAL AREA NETWORK ( WLAN ) DAN HOTSPOT PADA AMIK DIAN CIPTA CENDIKIA ( DCC ) PRINGSEWU. JISN (Jurnal Informatika Software Dan Network), 02(01), 15-22.

Job Street. (2021). Network Engineer Jobs. Retrieved June 9, 2021, from Job Street website: https://www.jobstreet.co.id/en/job-search/network-engineer-jobs/

JobsDB. (2021). Network Engineer Jobs. Retrieved June 9, 2021, from JobsDB website: https://th.jobsdb.com/th/search-jobs/network-engineer/1

Kurniawan, D. F., Widiyastuti, A., Studi, P., Informatika, M., Studi, P., Informatika, M., ... Queue, S. (2021). Manajemen Bandwidth Menggunakan Simple Queue Dengan Router Mikrotik Pada Smp 
Negeri 1 Sumberejo. JISN (Jurnal Informatika Software Dan Network), 02(01), 23-28.

Rahman, T., Sumarna, S., \& Nurdin, H. (2020). Analisis Performa RouterOS MikroTik pada Jaringan Internet. INOVTEK Polbeng - Seri Informatika, 5(1), 178. https://doi.org/10.35314/isi.v5i1.1308

Ridho, F., Yudhana, A., \& Riadi, I. (2016). Analisis Forensik Router Untuk Mendeteksi Serangan Distributed Danial of Service (DDoS) Secara Real Time. Annual Research Seminar 2016, 2(1), 111-116. Retrieved from http://ars.ilkom.unsri.ac.id

Sistem, R. (2021). Metode PCQ dan Queue Tree untuk Implementasi Manajemen Bandwidth. JURNAL RESTI, 1(10), 407-412.

Tasanah Assakur, Y. H., Fahrudin, M. S., \& Ferdiansyah, F. (2020). Implementasi API Mikrotik untuk Management Router Berbasis Android (Studi Kasus: PT Sigma Adi Perkasa). Jurnal Sains Dan Informatika, 6(1), 92-101. https://doi.org/10.34128/jsi.v6i1.217 